\title{
EMOTIONAL EXHAUSTION AND JOB SATISFACTION OF TOUR GUIDES IN RURAL AREAS
}

\author{
Željko Anđelkovićc ${ }^{1}$ Aleksandra Dragin ${ }^{2}$, Sanja Božic ${ }^{3}$, Kristina Košićc
}

\begin{abstract}
The purpose of this study was to determinate the job satisfaction and emotional exhaustion of tour guides in rural areas and to show how these two concepts are related to each other. A total of 102 tour guides, who lead tours or have experience in leading tours in rural areas took part in the questionnaire and the results were given and processed in SPSS version 17. Tour guides have a great importance in interpretation of rural areas as well as a significant role in presenting local customs and products in rural tourism. Exploring their satisfaction but also emotional exhaustion is of paramount importance for maintaining their excellence in interpretation of these areas. The results indicate that job satisfaction is still not on satisfying level, while emotional exhaustion is under acceptable limits. The results also showed that there is a negative connection between these two concepts. The obtained data should be beneficial not only to tour-operators but also to other tourism-related companies dealing with FDA (Front Desk Activities) and employees in rural tourism: the data about job satisfaction and emotional exhaustion of tour guides can be used in developing management and work motivation strategies. The profound insight in job satisfaction and emotional exhaustion is important in order to achieve business excellence of tour guides in rural areas.
\end{abstract}

Key words: tour guides, rural areas, job satisfaction, emotional exhaustion, business excellence

JEL: Q13, Q15

1 Željko Anđelković M.A., Ph.D. Student of Tourism, Department of Geography, Tourism and Hotel Management, Faculty of Science, Novi Sad, Dositeja Obradovića Square no. 3, 21000 Novi Sad, Phone: +381 605595 306, E-mail: zeljkozelja@yahoo.co.uk

2 Aleksandra Dragin Ph.D., Associate Professor, Department of Geography, Tourism and Hotel Management, Faculty of Science, Novi Sad, Dositeja Obradovića Square no. 3, 21000 Novi Sad, Phone: + 38163 8306114, E-mail: sadragin@gmail.com

3 Sanja Božić Ph.D., Assistant, Department of Geography, Tourism and Hotel Management, Faculty of Science, Novi Sad, Dositeja Obradovića Square no. 3, 21000 Novi Sad, Phone: + 38163622 115, E-mail: sanja.bozic.89@gmail.com

4 Kristina Košić Ph.D., Associate Professor, Department of Geography, Tourism and Hotel Management, Faculty of Science, Novi Sad, Dositeja Obradovića Square no. 3, 21000 Novi Sad, Phone: +381 63569 116, E-mail: kristina.kosicCdgt.uns.ac.rs

EP 2017 (64) 1 (11-26) 


\section{Introduction}

Services in tourism industry are intangible - "services are performances, rather than objects, they cannot be seen, felt, tasted, or touched in the same manner in which goods can be sensed" (Zeithaml et al., 1985). It is specific in a way it does not sell physical things - except for food, souvenirs... but rather some tourist products made at the moment of their consumption. Due to these intangible tourist services it is necessary to have skilful staff ready to respond to the potential customers' needs and also to be ready to deal with sometimes very demanding tourists. Service occupations with a high level of face-to-face contact with customers are significantly different from other types of work, since they contain emotional demands (in the form of 'emotional performance for profit') beyond the scope of traditional conceptualizations of work (Sandiford, Seymour, 2007). "Tour guides are one of the key front-line players in the tourism industry" (Ap, Kevin, 2001) and specific in rural tourism because of their great importance in presenting the way of living in rural areas as well as customs of those people: customs should be one of the products in rural tourism. Further they say that "tour guides are the essential interface between the host destination and its visitors" (Ap, Kevin, 2001) and because of that it is necessary to have a good working environment as well as good conditions at work. It is also very important that tour guides understand very well the way of living in villages so they could present in good and interesting way. It can be noted that the style of leadership exercised by tour leaders is a form of service provision. "They have to take care of their guests from the beginning to the end of the tour while guiding them to scenic spots" (Wong, Lee, 2012).

The concept of emotional labour was introduced by Hochshild $(1979,1983)$ and defined it as managed heart in his book The managed heart: The commercialization of human feelings published by Berkley: University of California Press in 1983. According to Wong and Wang (Wong, Wang, 2009) emotional labour possesses the following characteristics (e.g. Hochschild, 1983; Morris, Feldman, 1996; Zapf, 2002): (a) emotional labour occurs in faceto-face or voice-to-voice interactions with customers; (b) emotions are displayed to influence other people's emotions, attitudes, and behaviours; and (c) the display of emotions has follow certain rules. Numerous authors emphasize the significance of tour guide's performances (Baarsky, 1992; Hill, 1986; Huang, et al., 2010, Huang, et al., 2015; Parasuraman, et al., 1988) and their service orientation on their emotional exhaustion (Pienaar, Willemse, 2008; Wong, Wang, 2009). The tour leader's performance within the service encounter not only affects the company's image, but also customer loyalty and word-of-mouth communication (Heung, 2008; Mossberg, 1995). "Good" is the enemy of "Excellent" (Collins, 2010) so the tour guides should give their maximum to achieve that excellence in order to have satisfied customers. He also said that most companies do not achieve excellence because they are good and pretty good and they satisfied with that (Collins, 2010); but in tourism "one of the definition of 'success' is satisfied tourists" (Song et al., 2012). It should be mentioned once again that the job satisfaction, employees' relationships and their attitude towards the potential clients are so easily noticeable in the tourism flow, starting from the moment when a potential customer enters a travel agent's and starts communication with the staff, up to the moment when a representative provides direct services at particular destination. Not all 
days are the same and it is not possible to be kind to the highest degree but as Morris and Feldman (Morris, Feldman, 1996) claimed, it is necessary to invest a bit of effort or work which are necessary to express one's emotions. The intensity of that effort would not be as big as the one somebody can have when expressing negative feelings towards setting. Such case can be, for instance, too high expectations of the management - which requires such employee to be extra motivated; it is also necessary him / her to invest some extra energy or to try to change the job position within the company in order not to blacken its reputation. Hochschild $(1979,1983)$ claims that there is a kind of a rulebook of expectations related to the attitude the staff should display while providing different services. This can be applied onto the sphere of tourism - clients think that apart from e.g. being kind, polite, efficient, a person employed in this sector has to be ready to provide answers to all tourist's questions related to the particular destination; moreover he/she has to have answers for the questions that are not destination related and not so typical and thus he/she has to be sometimes even invisibly present. Based on Ashforth's belief (Ashforth, Humphrey, 1993) - Ekman (Ekman, 1973) names all of these norms the ,display rules“" and they represent a codex that implies not only what emotions are adequate for a particular situation but also how to transmit and show them publicly. "Display rules refer to behaviour rather than internal states, it makes relatively easy for customers, managers, and peers to observe one's level of compliance with the rules“ (Ashforth, Humphrey, 1993).

The principal aim of this paper was to explore job satisfaction and emotional exhaustion of tour guides in rural areas, but also to explore the relationship between these two concepts. This important information should serve as a basis for suggesting the ways to decrees emotional exhaustion among employees and increase job satisfaction, which would certainly directly influence their business excellence in interpreting rural areas.

\section{Research methodology}

This paper will present the results of research on the 102 respondents who are or were engaged as tour guides in the rural areas. As not all tour guides lead tours to rural districts, the sample was not easy to collect. Before including a tour guide in the survey, they were asked if they lead tours to rural areas, or they had experience in interpretation of rural districts. The sample was collected with the assistance of tourist info centres and local and tourism organizations of Novi Sad, Belgrade and Nis.

The survey with tour guides was conducted in order to explore the two main concepts the emotional occupational burnout (emotional exhaustion of tour guides), and the job satisfaction.

The world scientific literature of the last decade has had works in this area while in Serbia it is still mostly unexplored. The terms emotional satisfaction and emotional exhaustion are often being mixed up. They are the two completely opposed terms with different meanings. The way in which the third party perceives a job we do can, but not necessarily, in a way, change our attitudes towards our own job.

The basic hypothesis of this survey is: 
With increase of job satisfaction of tour guides, the emotional exhaustion decreases.

Based on the main Hypothesis, the research also intended to explore in more detail relationship with these two concepts, by conducting correlation test between individual items of job satisfaction and emotional exhaustion.

The problem, subject and objectives of the research required the application of appropriate methods and techniques of research. The research used two basic methods: the analysis method and the questionnaire method.

Within the analysis method the following was used: a method of documents' content analysis, using the technique of direct quantitative (statistical) analysis of documents' content and a method of structural analysis using the technique of classical qualitative method of documents' content analysis. The statistical data analysis was done in SPSS program.

A form of testing in the survey technique was used in the research, in particular, a written survey with standardized written questionnaire.

\section{Questionnaire design}

The questionnaire consists of three parts. The first part includes socio-demographic characteristics of respondents (gender, age, education and monthly income). The second part consists of a questionnaire for measuring emotional exhaustion, adapted from the original questionnaire (Maslash Burnout Inventory), developed by Maslach and Jackson from 1986 (where emotional exhaustion of one of the three factors of burnout) while the third part consists of a questionnaire of job satisfaction of tour guide, adapted from Thareethip Laowirojanaku from 1999, (A Study of Key Factors Affecting the Degree of Job Satisfaction of Tour Guide in Bangkok, Thailand). In the second and third parts, respondents were asked to measure the level of their agreement or disagreement with the various statements. The answers were measured by 5-point Likert scale (1-I totally disagree, 2-I disagree, 3- I am not sure, 4 - I agree, 5 - I totally agree).

\section{Procedure}

The research was carried out during March, April and May 2016. A standard pen and paper questionnaire was distributed to tour guides after their return from their tours in various tourist destinations. One part of the sample (32 out of 102) was reached by sending a questionnaire by e-mail. As a final result, the total of 102 completed questionnaires was collected.

\section{Review of the scientific literature}

"The tour guiding profession has been the "Cinderella" of the tourism industry: attractive, useful, but often neglected" (Mak et al., 2011). A very common problem that occurs in providing services, at work that requires communication with people and in the relationship between an employer and an employee is the emotional exhaustion or excessive overwork. It can happen at the moment of selling (tourist) services or among the employees at the workplace. A burnout syndrome, according to Maslach, is a phenomenon began to appear 
with some regularity in the 1970s in the United States, especially among people working in the human services (Maslach et al., 2001). In their work they define burnout as "an emotional exhaustion, depersonalization, and diminished personal accomplishment, found within human service professions" (Maslach et al., 2001). "A common symptom of emotional exhaustion is anxiety at the thought of going to work. Often this can be exacerbated as individuals become frustrated or angry with themselves as they realize they cannot give to clients and/or the company the same kind of enthusiasm as in the past" (Babakus et al., 1999). "Depersonalization is an attempt to put distance between oneself and service recipients by actively ignoring the qualities that make them unique and engaging people" (Maslach et al., 2001). The emotional exhaustion is a process that starts with physical and later on mental tiredness and which leads to declining working capability and finally to the diminished desire to work anything. Connected with them Wong claimed that performing emotional labor may lead to burnout, dissatisfaction with the job and finally a high turnover rate. A high turnover rate leads to higher recruitment and training cost. "The job rotation and a well-defined career path are thus helpful when the tour leaders suffer from emotional exhaustion and burnout" (Wong, Wang, 2009). The exhaustion component represents the basic individual stress dimension of burnout. It refers to feelings of being overextended and depleted of one's emotional and physical resources. "The cynicism (or depersonalization) component represents the interpersonal context dimension of burnout. It refers to a negative, callous, or excessively detached response to various aspects of the job" (Maslach et al., 2001).

This negative attitude can turn into a harsh, insensitive or even maladjusted behavior or withdrawal from others. In the tourism business, where direct contact between all the participants is almost necessary, this is the moment when the job should be given up at least for a while. Emotionally exhausted people with the occupational burnout cannot be good representatives of a tourist product, destination or agent. A job of a tourist guide is directly related to the emotional output and there should not be neither a reduced willingness to do the job nor any lack of emotion. Although the job has to be done without coming into close relationships with the passengers, a certain amount of participation in their travelling life is required because while being displaced from their homes and comfortable armchairs the only security they see is in the tourist guides. Therefore, especially in the tourism field, every occupational burnout, every absence of emotion and just getting the job done are signs to stop doing that job!

Every company needs a good business climate and good organization. There are many definitions of the organization, and Argyris (Argyris, 1977) require, as a minimum, employees who have skills to produce a product or a service. He looks at the organization as an open system with internal energy processes and feedback mechanism for corrections. The central focus is related to the psychological energy expressed in human needs and behaviors. As can be seen in this modern theory of organization mutual communication between employees and their adaptation to new situations is a condition sin qua non, and the treatment of employees and their emotional stability are crucial in all theories of organization since any particular tourist company is a living organism! 
According to Florida (Florida, 2002) creativity is "a crucial source of competitive advantage on the market". This is especially applicable to tourism. Many agencies sell the same services, but some are more successful at it. One can ask him/herself" What is the secret of that success? The emotional output / efforts that their employees have? The package? The agency image?"

An occupational burnout syndrome is defined by considering individual factors and the factors related to different situations. Situational factors imply that the occupational burnout syndrome is caused by (Dedić, 2005):

- the characteristics of the work place (the quantitative requirements- too many tasks and overtime work, qualitative reasons- conflicts and a lack of coworkers' support);

- the professional characteristcs related to the work (daily tasks, pressure and conflicts) and those related to the clients (communication and getting in touch with them frequently);

- having a job that seems to be confronted with death;

- the balance between work and emotions (requirements to suppress or express one's feelings, empathy);

- organisational characteristics (a type of job position).

\section{Results and discussion}

\section{Socio-demographic characteristics of the respondents}

The sample consists of the total of 102 respondents whose profession is tour guide. The results suggest that there were $44.1 \%$ of female respondents while $55.9 \%$ were male. Such figures are reasonable since this profession is dominated by men due to the fact that they are usually dislocated from home and have the stamina to go on several tours in a row and sometimes to stay there for a long time. It also has to do with tradition and patriarchal point of view that - a woman is the one who stays at home (to cook) and raise the children while a man makes a living and travels.

According to questionnaire most of the guides are 26 to 35 years old and such fact was something expected due to the fact that this job is considered to be a part-time job rather than steady one. There is a fluctuation in the travel industry even worldwide; in Serbia, a country going through the transition period for more than a decade, many of them are discouraged to leave their jobs and tend to have a steady one. As respondents get older their number declines - and from the social aspects it is reasonable since - many of them have families so it is not easy to stay away from home so often. Younger generation that come are more endurable and fresh - so the possibility to experience emotional exhaustion and burnout is significantly decreased. Young people find the job of a tour guide very interesting because they discover some new destinations by themselves and at the same time they have the opportunity to earn some money.

The number of respondents having high school and university education is the same. The number of respondents having $\mathrm{MA} / \mathrm{MSc}$ or $\mathrm{PhD}$ education is negligible (only seven of them) 
as well as the number of those having college degree (13.7\%). Such data is not surprising since in Serbia there is an increase in the number of students who majored in tourism at universities, working as tour guides but at the same time there is a big portion of employees in the sector of tourism having high school degree. An important thing to mention is the fact that there was a discontinuation in education of young tourist professionals at universities in Serbia from the 1980s until the first decade of the 1990s (the department of tourism at Belgrade University was discontinued by the end of the 1980s while the other one was started at the University of Novi Sad in the first decade of the 1990s). It is also important to mention that the profession of the tour guide is not meant only for those who graduated at university with major in tourism - there are many exceptional tour guides who majored in history or fine arts.

The results also indicated that most of the respondents have an income range from $€ 301$ to $€ 450$ and this sum can be considered as decent one; however there are twenty three respondents $(22.6 \%)$ with incomes ranging from $€ 451$ to $600 €$ and that can be considered to be a bit higher than the average one in Serbia. One can earn more money when going on longer tours and that are physically more requiring and that money serves as a sort of "compensation" for the absence from home and family. Once again it is important to point out that so called invisible "part" of the income which actually is another chance for a guide to re-visit a particular destination and see some of his/her friends and co-workers and that is why we it can be said that this social moment is of great importance. The detailed information about socio-demographic characteristics of respondents are shown in Table 1.

Table 1. Socio-demographic characteristics of the respondents

\begin{tabular}{|lc|lc|}
\hline Gender & & Education \\
\hline & & Secondary school & $37.3 \%$ \\
Male & $55.9 \%$ & Higher school & $13.7 \%$ \\
Female & $44.1 \%$ & Faculty & $42.1 \%$ \\
& & Master/PhD & $6.9 \%$ \\
\hline Age & & & \\
\hline $17-25$ & $26.5 \%$ & Monthly income & \\
$26-35$ & $51.0 \%$ & $<150$ eu & $5.9 \%$ \\
\hline $36-45$ & $17.6 \%$ & $151-300 \mathrm{eu}$ & $24.5 \%$ \\
\hline $46-55$ & $4.9 \%$ & $301-450 \mathrm{eu}$ & $37.3 \%$ \\
& & $451-600 \mathrm{eu}$ & $22.5 \%$ \\
\hline
\end{tabular}

Source: Data obtained from SPSS analysis 


\section{Job satisfaction of tour guides in rural areas}

The analyses were conducted in order to explore a job satisfaction of tour guides included in the sample. The results show that the Mean Value for job satisfaction is 3.11 (Std.=.356), which tells us that tour guides generally are not so satisfied with their job, and that there is still a lot of room for improvement in this field. A further analysis of the items of job satisfaction (Table 2) gives us a better insight in the elements tour guides are satisfied with the most and those they are satisfied the least.

Table 2. Mean of the items of job satisfaction of tour guides

\begin{tabular}{|l|l|l|}
\hline Items of Job satisfaction & Mean Value & Std. deviation \\
\hline $\begin{array}{l}\text { 1. Your job does not relate to your knowledge and experience and } \\
\text { makes you feel uncomfortable }\end{array}$ & $\mathbf{4 . 0 3}$ & 1.141 \\
\hline 2. You will be more successful to work in another job & $\mathbf{3 . 6 2}$ & 1.231 \\
\hline 3. Your current position is lower than your & $\mathbf{3 . 4 4}$ & 1.561 \\
\hline $\begin{array}{l}\text { Qualification } \\
\text { 4. You are satisfied to work with full of knowledge and capability }\end{array}$ & 4.12 & .946 \\
\hline 5. Your colleague usually listen to your opinion & 3.38 & 1.015 \\
\hline 6. You are satisfied the quantity of your job & 3.15 & 1.105 \\
\hline 7. You will be taken care by the company whenever you get an accident & $\mathbf{2 . 5 9}$ & 1.480 \\
\hline 8. Supervisor manages workers unfairly & $\mathbf{3 . 7 6}$ & 1.232 \\
\hline $\begin{array}{l}\text { 9. Supervisor never take for granted whenever you are well-done your } \\
\text { job }\end{array}$ & 3.18 & 1.141 \\
\hline 10. Your company is well-known in tourism industry & 4.06 & .886 \\
\hline 11. Tourist guide is honourable job & 4.03 & 1.114 \\
\hline 12. Atmosphere in your workplace is nice & 4.00 & 1.044 \\
\hline 13. You have freedom in work & 4.12 & .844 \\
\hline 14. Your job is always appreciated from executive & 3.65 & .981 \\
\hline 15. You feel inconvenient in cooperation & 1.50 & .826 \\
\hline 16. Salary is enough & $\mathbf{3 . 1 2}$ & 1.094 \\
\hline 17. Lack of variety in your job is boring & $\mathbf{1 . 9 1}$ & 1.190 \\
\hline 18. You are often offered to participate in training courses & 3.41 & 1.131 \\
\hline 19. Supplies and equipment are not enough & 2.18 & 1.314 \\
\hline 20. You have got special right to go some vacation assigned places & 3.26 & 1.524 \\
\hline
\end{tabular}

Source: Data obtained from SPSS analysis

From Table 2 we can see that the major problems for dissatisfaction of tour guides are that they consider their job does not relate to knowledge and experience they have, they think they would be more successful in other job and that they think that their current position is lower than their qualifications. This is a reasonable finding since almost half of the respondent have 
finished Faculty or Master or $\mathrm{PhD}$ and are highly educated people who consider they deserve better job positions. The research showed that this is the major cause of their dissatisfaction with the job. In the conditions of the high level of unemployment rate in Serbia, people very often accept job positions which do not correspond to their level and of education, and this causes high level of dissatisfaction with their job. Results also indicate that respondents are not so sure whether they would be taken care by the company whenever they get an accident and also think that supervisor manages workers unfairly. This implies that they don't have enough protection from the companies they work for. Also, they are not so satisfied with the salary they have, and from Table 1 we can see that $67.7 \%$ of them have average and bellow average salary, which they probably consider to be low in comparison with their level of education. On contrary, all other analyzed factor showed to be quite satisfactory, especially freedom, atmosphere at work and notion they work a honourable job.

\section{Emotional exhaustion of tour guides in rural areas}

The results of descriptive statistics indicate that mean value for emotional exhaustion of tour guides is 2.42 ( $\mathrm{Std} .=728$ ). At first glance, it can be seen that this is not alarming situation, but further analysis indicate that mean value of emotional exhaustion vary from 1.41 to 4.42 , showing that there are tour guides who have a really high level of emotional exhaustion.

The analysis was also conducted to explore the main value of the single items within Emotional exhaustion. The results are presented in table 3.

Table 3. Mean of the answers for items of emotional exhaustion of tour guides

\begin{tabular}{|l|r|r|}
\hline Items of emotional exhaustion & Mean & \multicolumn{1}{|l|}{ Std. deviation } \\
\hline 1. I feel emotionally drained at work. & 2.32 & 1.430 \\
\hline 2. I feel used up at the end of the day. & $\mathbf{3 . 7 6}$ & 1.075 \\
\hline $\begin{array}{l}\text { 3. I feel fatigued when I get up in the morning and have to face } \\
\text { another day on the job. }\end{array}$ & 2.15 & 1.019 \\
\hline 4. Working with people is really a strain on me. & 2.32 & 1.173 \\
\hline 5. I feel burned out from my work. & 2.38 & 1.181 \\
\hline 6. I feel frustrated on my job. & 1.53 & 1.022 \\
\hline 7. I feel I am working too hard on my job. & $\mathbf{3 . 0 9}$ & 1.443 \\
\hline 8. Working with people directly puts too much stress on me. & 1.97 & 1.141 \\
\hline 9. I feel like I am at the end of my rope & 2.29 & 1.219 \\
\hline
\end{tabular}

Source: Work of authors.

From table 3 we can see that the items I feel used up at the end of the day and I feel I am working too hard on my job have higher values compared to all other items of emotional exhaustion (higher than 3), while other items are still not indicating alarming situation in terms of emotional exhaustion. This can be explained by long working hours of tour guides and the fact that most of them consider they are not enough paid for it. 


\section{Relationship of emotional exhaustion and job satisfaction}

As it has been already pointed out emotional exhaustion is the core of the burnout syndrome (Maslach, 1982). It is exactly what happens in the service-oriented companies, where it is necessary have a direct contact very often and that is why such communication along with a wide range of other stressful activities lead to this burnout syndrome i.e. you feel tired or used up. "Burnout is a metaphor that is commonly used to describe a state of mental weariness" (Schanfeli \& Bakker, 2004, 294). Gaines and Jermier (Gaines \& Jermier, 1983, 569) say that "emotional exhaustion is the dimension of burnout that seems most applicable to occupation other than human services". Further they say that burnout has been almost exclusively associated with those who deal with clients and people working in tourism industry, or are directly connected with another people (clients). Even though the top managers of the tour operators are not exposed to the direct communication with clients they can suffer from this syndrome too since they often receive the clients' complaints, letters where they express their dissatisfactions and requests so that they have to deal with all of them.

The basic hypothesis of this survey states: If you are satisfied with the job, the level of emotional exhaustion decreases.

Table 4. Correlation between job satisfaction and emotional exhaustion

\begin{tabular}{|l|l|l|l|}
\hline \multicolumn{2}{|c|}{} & $\begin{array}{l}\text { E m otion a I } \\
\text { exhaustion }\end{array}$ & Job satisfaction \\
\hline \multirow{4}{*}{ Emotional exhaustion } & Pearson Correlation & 1 & $-.470^{* *}$ \\
\cline { 2 - 4 } & Sig. (2-tailed) & & .005 \\
\cline { 2 - 4 } & $\mathrm{N}$ & 102 & 102 \\
\hline \multirow{3}{*}{ Job satisfaction } & & $\begin{array}{l}\text { E m otion a I } \\
\text { exhaustion }\end{array}$ & Job satisfaction \\
\hline \multirow{2}{*}{$* *$ Correlation is significant at the 0.01 level (2-tailed). } & 1 \\
\cline { 2 - 4 } & Pearson Correlation & $-.470^{* *}$ & 102 \\
\cline { 2 - 4 } & Sig. (2-tailed) & .005 & 102 \\
\hline
\end{tabular}

Source: Data obtained from SPSS analysis

As it can be seen from the table, that there is a negative correlation between job satisfaction and emotional exhaustion, indicating that when job satisfaction rises the level of emotional exhaustion declines. This indicates that the basic hypothesis of this survey can be accepted.

Such correlation between emotional exhaustion and job satisfaction can be applied to other type of industries but at the same time it can be said that it is most characteristic of tertiary one where tourism actually belongs since there is a frequent and direct communication with customers that is sometimes even necessary so that the good job can be adequately evaluated. After a tour finishes, there are questionnaires for tourists that they need to fill out; sometimes they talk about the tour or follow different forms and comments.

After this, correlations between emotional exhaustion and items of job satisfaction (total of 18 items) have been explored. The results indicated that there is a negative correlation 
between emotional exhaustion and good atmosphere at work, but also that there is a negative correlation between emotional exhaustion and the item "I think I would be more successful doing the other job“. However, there are no significant correlations between other items of job satisfaction and emotional exhaustion.

Table 5. Significant correlation between emotional exhaustion and items of job satisfaction

\begin{tabular}{|c|c|c|c|c|}
\hline & & $\begin{array}{l}\text { Emotional } \\
\text { exhaustion }\end{array}$ & $\begin{array}{l}\text { I think I } \\
\text { would be more } \\
\text { successful doing } \\
\text { the other job } \\
\end{array}$ & $\begin{array}{l}\text { Good } \\
\text { atmosphere } \\
\text { at work }\end{array}$ \\
\hline \multirow{4}{*}{ Emotional exhaustion } & Pearson Correlation & 1 & $.418^{*}$ & $-.372^{*}$ \\
\hline & Sig. (2-tailed) & & .014 & .030 \\
\hline & $\mathrm{N}$ & 102 & 102 & 102 \\
\hline & & $\begin{array}{l}\text { Emotional } \\
\text { exhaustion }\end{array}$ & $\begin{array}{l}\text { I think I } \\
\text { would be more } \\
\text { successful doing } \\
\text { the other job } \\
\end{array}$ & $\begin{array}{l}\text { Good } \\
\text { atmosphere } \\
\text { at work }\end{array}$ \\
\hline \multirow{3}{*}{$\begin{array}{l}\text { I think i would be } \\
\text { more successful doing } \\
\text { the other job }\end{array}$} & Pearson Correlation & $.418^{*}$ & 1 & .071 \\
\hline & Sig. (2-tailed) & .014 & & 691 \\
\hline & $\mathrm{N}$ & 102 & 102 & 102 \\
\hline \multirow{3}{*}{$\begin{array}{l}\text { Good atmosphere at } \\
\text { work }\end{array}$} & Pearson Correlation & $-.372^{*}$ & .071 & 1 \\
\hline & Sig. (2-tailed) & .030 & .691 & \\
\hline & $\mathrm{N}$ & 102 & 102 & 102 \\
\hline
\end{tabular}

Source: Data obtained from SPSS analysis

Table 5 indicates that the correlation exists, meaning if a tour guide works in a good atmosphere the level of his/her emotional exhaustion decreases. Such outcome seems to be reasonable since everybody wants a good and adequate atmosphere especially when it comes to people who work with other people. This is because it happens very often that some small signs of kindness along with non-verbal communication can significantly influence tourists' satisfaction. It is sometimes necessary to praise the employees and his/her efforts and that the clients are becoming more and more satisfied- such things can make him/her - become even better, loyal and trustworthy worker. Good atmosphere at work is very important because it can help the employees become more creative and do their best. Since tourism as a kind of industry that aims to provide satisfaction of its tourists and make better profits, such adequate atmosphere is essential because it serves as a basis for the sense of security and belonging of the team that tries to achieve it.

Moreover, if he/she considers that he/she would be more successful doing other job, the emotional exhaustion increases. This finding might be connected with the fact that respondents are not so satisfied with their salary but also with the fact they think they have knowledge and experience which does not correspond to this job. This can be supported with the fact that majority of respondents obtained university degree. Also, their salary is enough only to meet their basic needs and wishes. According to National department for statistics, the 
average salary in Serbia in March 2016 was 375 eu, and these results indicate that majority of tour guides earn from 301 to 450 euros. If we consider statistical data which tell us that if some of them support three - member family in Serbia it is necessary to earn about $550 \mathrm{eu}$, which is around 183 eu per person - this indicates that they have only $200 \mathrm{eu}$ left to satisfy other specific needs such as culture, art, tourism etc. As majority of respondents are highly educated people who account for majority in public cultural events and travelling, it is the fact that not much money is left to satisfy these needs. The job of tour guides requires a high level of education, tolerance as well as "capability to play at the first line of the front" (Ap \& Kevin, 2001, 551) which means that they are more susceptible to emotional exhaustion. For instance, employees in other professions, such as, IT sector, do not have so much direct contacts with people and their average salaries are much higher, so it is reasonable that respondents consider that they would be more successful in other job with the same input of time and energy, which would lower their level of emotional exhaustion.

\section{Conclusion}

As a phenomenon of interpersonal relationships, tourism keeps evolving. Rural areas are suffering immense changes and because of that it is important to save their authenticity: tour guides might serve as bridges that could contribute in understanding that way of living and rural tourism is a tool to show tourist all these intangible and tangible heritage. There are few things that cannot be presented and shown in terms of tourism. Since tourism is a phenomenon that provides intangible services, it is necessary to examine it from different aspects and motivation and the way of providing services are definitely some of them. In this research, it has been proven that emotional exhaustion decreases when employees are satisfied with the job. The important finding is also that emotional exhaustion declines when there is a good atmosphere at work but increases when employees are think that they would be more successful in doing other job. "Tour guides are one of the key front-line players in the tourism industry" (Ap, Kevin, 2001) it is necessary to deal with their satisfaction at work since business excellence depends on them to a great extent. They form the brand of the travel agency as well as of the destination tourist's visit. This paperwork has to do with the research about their satisfaction at work and to what extent and why they are emotionally exhausted. To achieve business excellence is definitely the goal any employee in hospitality sector attains to - especially in tourism where people spend both their free time and money. Business excellence is such a challenge for the employees not only in tourism sector (as well as in all sectors connected with human economy resources and services) that only those who achieve it can hope to make profit.

It is up to these whether the tourists would be satisfied and whether the company would make profit and maintain solvency. It is important to have in mind that tourism is an economic category but in the future it is necessary for all tourist transitions to contain prefix "sustainable". There is no unique definition to describe what it means to be satisfied with you work though in the 1970s Locke said that it is: "a pleasurable or positive emotional state resulting from an appraisal of one's job or job experiences" (Locke, 1976). It is only a satisfied and motivated guide who can generate satisfied customers and this is something 
that must be worked on continuously. There must not be any occupational burnout. It is very important to have an adequate response to the early stage of this syndrome since it does not have only a psychophysical effect on an individual; moreover the economic drawback caused by a work-shy and dissatisfied employee is inevitable in any company and especially in tourism industry where they directly communicate with tourists.

Burnout syndrome and work satisfaction are inversely proportional so as the work satisfaction declines, burnout syndrome increases and vice versa.

Any good HR team has a fair treatment of their employees and thus tries to postpone burnout as long as it is possible or at its best, to eliminate it from the company. In tourism, fluctuation is very common- employees change their job positions, they attend different workshops so that it is really possible to move boundaries when it comes to this phenomena.

\section{Literature}

1. Ap, W. J., Kevin, K. F. W. (2001): Case study on tour guiding: professionalism, issues and problems, Tourism Management, Vol. 22, no. 5, pp. 551-563, Elsevier B.V., Amsterdam, The Netherlands.

2. Argyris, C. (1977): Understanding Human Behavior in Organizations, John Wiley and Sons, New York, USA.

3. Ashforth, B. E., Humphrey, R. H. (1993): Emotional Labor in Service Roles: The influence of Identity, Academy of Management Review, Vol. 18, no. 1, pp. 88-115, Academy Management, Briar Cliff Manor NY, USA.

4. Babakus, E., Cravens, D. W., Johnston, M., Moncrief, W, C. (1999): The role of emotional exhaustion in sales force attitude and behavior relationship, Journal of the Academy of Marketing Science, Vol. 27, no. 1, pp. 58-70, Springer US, New York, USA.

5. Barsky, J. D. (1992): Customer satisfaction in the hotel industry: Meaning and measurement, Journal of Hospitality and Tourism Research, Vol. 16, no. 1, pp. 5173, SAGE Publications, New York, USA.

6. Collins, J. (2010): Business excellence: Why Some Companies Succeed In Taking The Leap From "good" to "excellent "and Others Don't?, Curtea Veche Publishing House., Bucharest, Romania (Original work published 2001).

7. Dedić, G. (2005): Sindrom sagorevanja na radu, Vojnosanitetski pregled, Vol. 11, pp. 851-855, Uprava za vojno zdravstvo MO Srbije, Beograd, Srbija.

8. Ekman, P. (1973): Cross-culture studies in a facial expression, In: P. Ekman, ed., pp. 169-222, Darwin and facial expression: A century of research in review. Academic Press, New York, USA.

9. Florida, R. (2002): The rise of the Creative Class, Basic Books, New York, USA.

10. Gaines, J., Jermier, J. M. (1983): Emotional Exhaustion in a High Stress Organization, Academy of Management Journal, Vol. 26, no. 4, pp. 567-586, Academy of Management, Briar Cliff Manor NY, USA. 
11. Heung, V. C. S. (2008): Effects of tour leader's service quality on agency's reputation and customers'word-of-mouth, Journal of Vacation Marketing, Vol. 14, no. 4, pp. 305-315, SAGE Publications, New York, USA.

12. Hill, D. J. (1986): Satisfaction and consumer services, Advances in Consumer Research, Vol. 13, no. 1, pp. 311-315, Association for Consumer Research Labovitz School of Business \& Economics University of Minnesota, Duluth MN, USA.

13. Hochschild, A. (1979): Emotion work, feeling rules and social structure, American Journal of Sociology, Vol. 85, pp. 551-575, The University of Chicago Press, Chicago, USA.

14. Hochschild, A. (1983): The managed heart: Commercialization of human feeling, University of California Press, Berkeley, USA.

15. Huang, S., Hsu, C. H. C., Chan, A. (2010): Tour guide performance and Tourist Satisfaction: a Study of the Package Tours in Shangahai. Journal of Hospitality \& Tourism Research, Vol. 34, no. 1, pp. 3-33, SAGE Ppublications, New York, USA.

16. Huang, S., Weiler, B., Assaker, G. (2015): Effects of Interpretive Guiding Outcomes on Tourist Satisfaction and Behavioral Intention, Journal of Travel Research, Vol. 54, no. 3, pp. 14-358, SAGE Publications, New York, USA.

17. Laowirojanakul, T. (1999): A Study of key factors affecting the degree of job satisfaction of tour guide in Bangkok, Thailand (thesis), Rochester Institute of Technology, New York, USA.

18. Locke, E. A. (1976): The nature and causes of job satisfaction, In M. D. Dunette, ed., Handbook of Industrial and Organizational Psychology, Rand McNaily, Chicago, USA.

19. Mak, A. H. N., Wong, K. K. F., Chang, R. C. Y. (2011): Critical issues affecting the service quality and professionalism of the tour guides in Hong Kong and Macau, Tourism Management, Vol. 32, no. 6, pp. 1442-1452, Elsevier B.V., Amsterdam, The Netherlands.

20. Maslach, C. (1982): The cost of caring, Prentice - Hall, Englewood Cliffs, New Jersey, USA.

21. Maslach, C., Jackson, S. E. (1986): Maslach Burnout Inventory, (Second Edition), Consulting Psychologists Press, Paolo Alto CA, USA.

22. Maslach, C., Schaufeli, B. W., Leiter, M. P. (2001): Job burnout, Annual Review Psychology, Vol. 52, pp. 397-422, Annual Reviews Inc., Palo Alto CA, USA.

23. Morris, J.A., Feldman, D. C.(1996): The Dimensions, Antecedents, and Consequences of Emotional Labor, Academy of Management Review, Vol. 21, no. 4, pp. 986-1010, Academy of Management, Briar Cliff Manor NY, USA.

24. Mossberg, L. (1995): Tour leaders and their importance in charter tours, Tourism Management, Vol. 16, no. 6, pp. 437-445, Elsevier B.V., Amsterdam, The Netherlands. 
25. Parasuraman, A., Zeithaml, V. A., Berry, L. L. (1998): SERQUAL: A multiple-item scale for measuring consumer perception of service quality, Journal of Retailing, Vol. 64, pp. 12-40, Elsevier B.V., Amsterdam, The Netherlands.

26. Pienaar, J., Willemse, S. A. (2008): Burnout, engagement, coping and general health of service employess in hospitality industry, Tourism Management, no. Vol. 29, no. 6, pp. 1053-1063, Elsevier B.V., Amsterdam, The Netherlands.

27. Sandiford, P., Seymour, D. (2007): The concept of occupational community revisited: Analytical and managerial implications in face-to-face service occupation, Work, Employment and Society, Vol. 21, no. 2, pp. 209-226, SAGE Publications, New York, USA.

28. Schaufeli, W, B., Bakker, A. B. (2004): Job demands, job resources, and their relaionship with burnout and engagement: a multi-sample study, Journal of Organizational Behavior, Vol. 25, no. 3, pp. 293-315, Wiley, New Jersey, USA.

29. Song, H., Veen, V. D. R., Li, G., Chen, J. L. (2012): The Hong Kong Tourist Satisfaction Index, Annals of Tourism Research, Vol. 39, no. 1, pp. 459-479, Elsevier B.V., Amsterdam, The Netherlands.

30. Wong, J. Y., Wang, C. H. (2009): Emotional labor of the tour leaders: and exploatory study, Tourism Management, Vol. 30, no. 2, pp. 249-259, Elsevier B.V., Amsterdam, The Netherlands.

31. Wong, J. Y., Lee, W. H. (2012): Leadership through service: An exploratory study of leadership styles of tour leaders, Tourism Management, Vol. 33, no. 5, pp. 11121121, Elsevier B.V., Amsterdam, The Netherlands.

32. Zapf, D. (2002): Emotion work and psychological well.being; a review of the literature and some conceptual consideration. Human Resource Management Review, Vol. 12, no. 2, pp. 237-268, Elsevier B.V., Amsterdam, The Netherlands.

33. Zeithaml, V, A., Parasuraman, A., Berry, L. L. (1985): Problems and Strategies in Service Marketing, Journal of Marketing, Vol. 49, no. 2, pp. 33-46, SAGE Publications, New York, USA. 


\title{
EMOCIONALNA ISCRPLJENOST I ZADOVOLJSTVO POSLOM TURISTIČKIH VODIČA U RURALNIM PODRUČJIMA
}

\author{
Željko Anđelkovic ${ }^{5}$, Aleksandra Dragin ${ }^{6}$, Sanja Božič , Kristina Košic ${ }^{8}$
}

\begin{abstract}
Apstrakt
Cilj autora ove studijeje utvrđivanje zadovoljstva poslomiemocionalne iscrpljenostiturističkih vodiča u ruralnim područjima, kao i da se istraži kako su ova dva koncepta međusobno povezana. Ukupno 102 turistička vodiča, koji vode ture ili imaju iskustvo u vođenju tura $\mathrm{u}$ ruralnim područjima učestvovalo je $\mathrm{u}$ istraživanju a rezultati su obrađeni u programu SPSS verzija 17. Turistički vodiči imaju veliki značaj u interpretaciji ruralnih područja, kao i značajnu ulogu u predstavljanju lokalnih običaja i proizvoda u ruralnom turizmu. Istraživanje njihovog zadovoljstva poslom, kao i emocionalne iscrpljenosti je od ključnog značaja za održavanje izvrsnosti u njihovoj interpretaciji ovih oblasti. Rezultati pokazuju da je zadovoljstvo posao još nije na zadovoljavajućem nivou, dok je emocionalna iscrpljenost još uvek u prihvatljivim granicama. Rezultati su takođe pokazali da postoji negativna veza između ova dva koncepta. Dobijeni podaci su od koristi ne samo za turoperatore već i druge kompanije u ruralnom turizmu: podaci o zadovoljstvu poslom i emocionalnoj iscrpljenosti turističkih vodiča mogu da se koriste u razvoju strategije njihove motivacije na poslu. Dublji uvid u zadovoljstvo poslom i emocionalnu iscrpljenosti je važno kako bi se održala poslovna izvrsnost turističkih vodiča u ruralnim područjima.
\end{abstract}

Ključne reči: turistički vodiči, ruralna područja, zadovoljstvo poslom, emocionalna iscrpljenost

5 Željko Anđelković M.A., Doktorant turizma, Departman za geografiju, turizam i hotelijerstvo, Prirodno matematički fakultet Novi Sad, Trg Dositeja Obradovića br. 3, 21000 Novi Sad, Telefon: +381 605595 306, E-mail: zeljkozelja@yahoo.co.uk

6 Prof. dr Aleksandra Dragin, vanredni profesor, Departman za geografiju, turizam i hotelijerstvo, Prirodno matematički fakultet Novi Sad, Trg Dositeja Obradovića 3, 21000 Novi Sad, Telefon: +381 638306 114, E-mail: sadragin@gmail.com

7 Dr Sanja Božić, asistent, Departman za geografiju, turizam i hotelijerstvo, Prirodno matematički fakultet Novi Sad, Trg Dositeja Obradovića 3, 21000 Novi Sad, Telefon: +381 63622 115, E-mail: sanja.bozic.89@gmail.com

8 Prof. dr Kristina Košić, vanredni profesor, Departman za geografiju, turizam i hotelijerstvo, Prirodno matematički fakultet Novi Sad, Trg Dositeja Obradovića 3, 21000 Novi Sad, Telefon: +381 63569 116, E-mail: kristina.kosicCdgt.uns.ac.rs 
ECONOMICS OF

AGRICULTURE

\section{CONTENT}

1. Željko Anđelković, Aleksandra Dragin, Sanja Božić, Kristina Košić

EMOTIONAL EXHAUSTION AND JOB SATISFACTION OF TOUR GUIDES IN RURAL AREAS . . . . . . . . . . . . . . 11

2. Sanja Đukić, Danica Glavaš-Trbić, Nikola Banjac

MANAGEMENT PROBLEMS OF RURAL DEVELOPMENT IN FRUŠKA GORA . . . . . . . . . . . . . . . . . . . . 27

3. Ivana Ilić, Bojan Krstić, Sonja Jovanović

ENVIRONMENTAL PERFORMANCES OF AGRICULTURE IN THE EUROPEAN UNION COUNTRIES . . . . . . . . . . . . . 41

4. Nataša Kljajić, Jonel Subić, Zorica Sredojević

PROFITABILITY OF RASPBERRY PRODUCTION

ON HOLDINGS IN THE TERRITORY OF ARILJE. . . . . . . . . . . 57

5. Aleksandar Maksimović, Zoran Grgić, Ferhat Ćejvanović

MULTI-ATTRIBUTE ANALYSIS OF ORCHARD ACCORDING

TO THE INTEGRATED PRODUCTION CONCEPT . . . . . . . . . . 69

6. Ozrislava Milinković, Branislav Jakić, Slobodan Vuksanović,

Dragana Macura, Milica Šelmić

MULTI- CRITERIA DECISION BASED APPROACH

TO SELECTING THE TYPE OF INDUSTRIAL HALLS

USED IN FOOD INDUSTRY $\ldots \ldots \ldots \ldots$. . . . . . . . . . 81

7. Gordana Nikić, Ljubiša Stamatović, Azra Sućeska

EMOTIONAL COMPETENCIES AND PERSONALITY

TRAITS OF MANAGERS IN MODERN AGROBUSINESS. . . . . . . .97

8. Vladimir Obradović, Nemanja Karapavlović

FINANCIAL REPORTING OF COMPREHENSIVE INCOME

IN THE FOOD AND BEVERAGE SECTOR

IN THE REPUBLIC OF SERBIA . . . . . . . . . . . . . . 113 
9. Aleksandar Ostojić, Nebojša Savić, Željko Vaško

CONSUMER ATTITUDES

ON BUYING FISH IN BANJA LUKA . . . . . . . . . . . . . . . 129

10. Radivoj Prodanović, Boris Kuzman, David Jovović, Lazar Ozegović

MARKET AND TRADE OF ORGANIC FRUITS IN SERBIA $\ldots . . .141$

11. Predrag Vukadinović, Aleksandar Damnjanović, Ljiljana Dimitrijević

ANALYSIS OF THE SALES AND INCOMES BETWEEN

DIFFERENT CATEGORIES OF AGRICULTURAL PRODUCTS . . . 157

12. Jugoslav Aničić, Svetlana Vukotić, Goran Maksimović

THE POSSIBILITIES AND LIMITATIONS

OF ENTREPRENEURSHIP DEVELOPMENT

IN AGRICULTURE IN SERBIA . . . . . . . . . . . . . . 171

13. Željko Bjelajac, Marijana Dukić - Mijatović, Joko Dragojlović

FOOD SAFETY AS ONE OF THE MAIN SAFETY $P$

REOCCUPATIONS OF A MODERN MAN . . . . . . . . . . . . . 191

14. Milan Bradić, Ljiljana Kosar, Lukrecija Djeri, Svetlana Vukosav, Vuk Garača

ECO-LABELLING OF ACCOMMODATION FACILITIES

AND ITS PERCEPTION BY RURAL TOURISTS:

CASE STUDY OF VOJVODINA . . . . . . . . . . . . . . 205

15. Vaso Jegdić, Iva Škrbić, Srđan Milošević

MODELS OF ENTREPRENURSHIP DEVELOPMENT

IN RURAL TOURISM DESTINATIONS IN VOJVODINA . . . . . . . 221

16. Duško Kuzović

MUSEUM OF VERNACULAR ARCHITECTURE OF WESTERN SERBIA

- Representative curtilages of the area surrounding middle

course of the river Drina and Podgorina . . . . . . . . . . . 239

17. Branko Mihailović, Zoran Simonović, Nikola Ćurčić

AGRICULTURAL RESOURCES AND DEVELOPMENT

PRIORITIES OF THE MUNICIPALITY OF STARA PAZOVA. . . . . 259

18. Radmilo Nikolić, Aleksandra Fedajev, Vidoje Stefanović, Silvana Ilić

THE AGRICULTURE SECTOR IN WESTERN BALKANS

- SOME CHARACTERISTICS OF DEVELOPMENT. . . . . . . . . . 275

19. Vladimir Njegomir, Rajko Tepavac, Nenad Ivanišević

ALTERNATIVE SOURCES OF FINANCING

ENTREPRENEURIAL UNDERTAKINGS IN AGRICULTURE . . . 295

Economics of Agriculture, Year 64, No. 1 (1-404) 2017, Belgrade 
20. Daniela Nuševa, Kristina Mijić, Dejan Jakšić

THE PERFORMANCES OF COFFEE PROCESSORS

AND COFFEE MARKET IN THE REPUBLIC OF SERBIA . . . . . . 307

21. Svetlana Roljević Nikolić, Predrag Vuković, Biljana Grujić

MEASURES TO SUPPORT THE DEVELOPMENT OF ORGANIC

FARMING IN THE EU AND SERBIA . . . . . . . . . . . . 323

22. ŽeljkoVojinović, Vera Zelenović, DragoCvijanović

PROGRAM OF STATE SUPPORT

TO AGRICULTURAL CREDITING. . . . . . . . . . . . . . . . 339

23. Nikola Vuksanović, Dragan Tešanović, Bojana Kalenjuk,

Milijanko Portić, Marija Knežević

SOCIO-DEMOGRAPHIC CHARACTERISTICS

AS DETERMINANTS OF DIFFERENCES

IN PERCEPTION OF LOCAL GASTRONOMY . . . . . . . . . . . . 359 